\title{
ARTICLE
}

Chronic myelogenous leukemia

\section{Therapeutic inhibition of FcyRllb signaling targets leukemic stem cells in chronic myeloid leukemia}

\author{
Oliver Parting ${ }^{1}$. Samantha Langer ${ }^{2} \cdot$ Maja Kim Kuepper ${ }^{1} \cdot$ Caroline Wessling $^{3} \cdot$ Shaoguang Li $^{4} \cdot$ Till Braunschweig $^{5}$. \\ Nicolas Chatain $\mathbb{D}^{1} \cdot$ Tiago Maié ${ }^{6}$. Ivan G. Costa $\mathbb{D}^{6} \cdot$ Martina Crysandt ${ }^{1} \cdot$ Michael Huber $\mathbb{D}^{7}$.

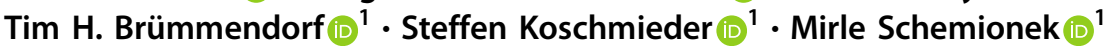

Received: 16 March 2020 / Revised: 2 July 2020 / Accepted: 7 July 2020 / Published online: 20 July 2020

(c) The Author(s) 2020. This article is published with open access

\begin{abstract}
Despite the successes achieved with molecular targeted inhibition of the oncogenic driver Bcr-Abl in chronic myeloid leukemia (CML), the majority of patients still require lifelong tyrosine kinase inhibitor (TKI) therapy. This is primarily caused by resisting leukemic stem cells (LSCs), which prevent achievement of treatment-free remission in all patients. Here we describe the ITIM (immunoreceptor tyrosine-based inhibition motif)-containing Fc gamma receptor IIb (Fc $\gamma \mathrm{RIIb}$, CD32b) for being critical in LSC resistance and show that targeting FcyRIIb downstream signaling, by using a Food and Drug Administration-approved BTK inhibitor, provides a successful therapeutic approach. First, we identified Fc $\gamma$ RIIb upregulation in primary CML stem cells. Fc $\gamma$ RIIb depletion caused reduced serial re-plaiting efficiency and cell proliferation in malignant cells. FcyRIIb targeting in both a transgenic and retroviral CML mouse model provided in vivo evidence for successful LSC reduction. Subsequently, we identified BTK as a main downstream mediator and targeting the Bcr-AblFc $\gamma$ RIIb-BTK axis in primary CML CD $34^{+}$cells using ibrutinib, in combination with standard TKI therapy, significantly increased apoptosis in quiescent CML stem cells thereby contributing to the eradication of LSCs.. As a potential curative therapeutic approach, we therefore suggest combining Bcr-Abl TKI therapy along with BTK inhibition.
\end{abstract}

Supplementary information The online version of this article (https:// doi.org/10.1038/s41375-020-0977-8) contains supplementary material, which is available to authorized users.

Mirle Schemionek

mschemionek@ukaachen.de

1 Department of Hematology, Oncology, Hemostaseology, and Stem Cell Transplantation, Faculty of Medicine, University Hospital RWTH Aachen, Aachen, Germany

2 Department of Transfusion Medicine, University Hospital Essen, Essen, Germany

3 Department of Neurosurgery, Clemens Hospital, Muenster, Germany

4 Department of Medicine, University of Massachusetts Medical School, Worcester, MA, USA

5 Department of Pathology, University Hospital RWTH Aachen, Aachen, Germany

6 Institute for Computational Genomics, Joint Research Center for Computational Biomedicine, RWTH Aachen University, Aachen, Germany

7 Institute of Biochemistry and Molecular Immunology, RWTH Aachen University, Aachen, Germany

\section{Introduction}

Chronic myeloid leukemia (CML) is caused by the Bcr-Abl translocation arising in the hematopoietic stem cell (HSC) compartment. The oncogenic Bcr-Abl tyrosine kinase induces a variety of signaling pathways that result in increased proliferation, differentiation, cytokine independence, and protection from apoptosis in the malignant cell clones [1-3]. Implementation of Bcr-Abl tyrosine kinase inhibitors (TKIs) showed remarkable clinical success with high response rates [4]. However, current therapies are often not curative, and even in patients responding optimally to Bcr-Abl inhibition, TKI discontinuation induces molecular relapse in about half of this patient cohort [5-7]. Bcr-Abl-positive HSCs are termed leukemic stem cells (LSCs) and this cell compartment contains quiescent cells that at least partially resist Bcr-Abl inhibition $[8,9]$. Quiescent LSCs therefore differ from cycling CML cells that usually undergo apoptosis upon Bcr-Abl targeting $[10,11]$. These resistant LSCs persist despite long-term TKI therapy in CML patients and are most likely the cause of disease recurrence upon TKI discontinuation. To increase the amount of patients achieving and remaining in treatment-free 
remission (TFR) therefore requires successful targeting of these LSCs.

Among many others, targeting JAK/STAT, IL-1, p53/ MYC signaling, or metabolic activity has recently been shown to impair LSC survival [12-16]. Eventually, these observations have given rise to clinical trials, but successful implementation into routine clinical application could not be achieved so far.

ITIM (immunoreceptor tyrosine-based inhibition motif) receptors are classified as negative regulators, as they can recruit phosphatases and in this way inhibit signal transduction. The ITIM-receptor Fc gamma receptor Ilb (FcyRIIb, $\mathrm{CD} 32 \mathrm{~b}$ ) is a member of the $\mathrm{Fc}$ receptor family, which is known for their function to equalize signaling pathways and cell activation, leading to a well-balanced immune response [17]. FcyRIIb is most broadly expressed on all leukocytes except natural killer and $\mathrm{T}$ cells, is the only member transmitting inhibitory signals, and is predominantly phosphorylated by the SRC family kinase LYN [18]. FcyRIlb was previously identified as a cooperative oncogene upon disease progression in a preleukemic NUP98-HOXA9 mouse model [19]. Recently, ITIM motif containing receptors LAIR1 and PirB were identified to support acute myeloid leukemia (AML) stem cell survival [20, 21], highlighting the importance of those receptor types for LSC biology.

In this study, we identified TKI-independent upregulation of the ITIM-containing receptor Fc $\gamma$ RIIb in primary murine leukemic stem and progenitor cells, as well as in primitive CML patient-derived $\mathrm{CD}^{+} 4^{+}$cells. Genetic depletion as well as short hairpin RNA (shRNA)-mediated knockdown impaired disease phenotype and LSC burden in vivo in a transgenic and retroviral CML mouse model. Subsequently, we identified the tyrosine kinase BTK as a main target of altered FcyRIIb downstream signaling, with BTK being activated only in FcyRIIb-expressing malignant cells. Implementation of ibrutinib (Ibr) to target BTK in combination with standard TKI therapy increased apoptosis in quiescent $\mathrm{CML} \mathrm{CD} 34^{+}$cells providing a novel curative approach using a Food and Drug Administration (FDA)approved drug, aiming to eradicate persisting LSCs.

\section{Materials and methods}

\section{Isolation and cell culture of primary cells}

Murine $\operatorname{lin}^{-}$bone marrow (BM) cells were isolated and applied with or without HoxB8-driven immortalization that was performed as described [22, 23]. Mononucleated cells (MNCs) were purified by density gradient centrifugation from peripheral blood (PB), leukapheresis, or BM biopsy (Ficoll, GE Healthcare, Solingen, Germany), and then cultured in Iscove's modified Dulbecco's medium and 20\%
BIT9500 (Stem Cell Technologies). Isolation of CD34 cells was performed from leukapheresis or BM biopsies using CliniMACS-CD34 or CD34-MicroBead Kit (human, Milteny Biotech, Bergisch Gladbach, Germany). For experimental procedures, cells were kept in low growth factor cocktail [9]. All cytokines were purchased from ImmunoTools (Friesoythe, Germany) or Milteny Biotech.

\section{Retroviral transduction}

Retroviral transduction was performed as described previously [24] using $\mathrm{CaCl}_{2}$ for transfection and retronectin (Takara Bio Inc., France) for transduction. Transduction was repeated two to three times on consecutive days.

\section{RNA expression analysis}

Differential expression analysis shown in Supplementary Fig. S17 was performed on the Gene Expression Omnibus dataset GSE2535. Data were acquired and analyzed using the GEOquery and limma R packages. Limma's voom normalization and linear model fitting procedure were applied to the data in order to obtain the differentially expressed genes. We considered the origin of the samples (Leipzig vs. Mannheim) as a batch-effect covariate and corrected for such when fitting the model. As in GSE2535_REF, non-adjusted $p$ values were used to identify the most differentially expressed genes. RNA extraction was performed using Trizol reagent (Thermo Fisher Scientific, Waltham, MA, USA). One microgram of total RNA was subjected to complementary DNA (cDNA) synthesis using the Moloney murine leukemia virus reverse transcriptase (Thermo Fisher). Gene expression was analyzed using TaqMan assays or SYBR Green method as described previously [25]. TaqMan Assays were purchased from Applied Biosystems (human FcrRIIb: Hs01634996_s1; murine FcyRIIb: Mm00438875_m1). Sequences for primer and probes are available in Supplementary Table S1.

\section{DNA constructs}

Fc $\gamma$ RIIb cDNA was amplified from cDNA of C57BL/6 wild-type $\mathrm{BM}$ using the following primer pairs: FcyRIIb_XhoI_F: GAACTCGAGATGGGAATCCTGCCG TTCCT and FcyRIIb_EcoRI_R: GAAGAATTCCTAAA TGTGGTTCTGGTAAT. PCR product and MSCV-IRESGFP vector were digested using XhoI and EcoRI. Positive clones were fully sequenced.

\section{FcyRIlb shRNA constructs}

FcyRIIb targeting shRNA and scrambled (scr) control shRNA retroviral constructs were generated using pMSCV- 
LTR-miR30-SV40-GFP vectors. shRNA oligonucleotide sequences are available in Supplementary Table S2.

\section{Cell culture}

32Dcl3 (named as 32D), K562, and KCL-22 (DSMZ, ACC 411, ACC 10, ACC 519) cells were cultured in RPMI media supplemented with 10-20\% fetal bovine serum and 1\% penicillin/streptomycin. Ten percent WEHI supernatant was used as IL-3 source.

\section{Colony formation assay}

Indicated cell numbers were resuspended in methylcellulose (MethoCult M3231, M3534, H4230 and H4434, Stem Cell Technologies) and colony-forming units were counted after 7-9 days.

\section{Immunoblotting}

Immunoblotting was performed as described previously [23]. The following antibodies were used for immunoblotting p27, pSTAT5Y694, STAT5, pCRKLY207; CRKL, pBTKY223, BTK, pERKY202/204; ERK, pp38Y180/182, p38, pcAbl, cAbl (Cell Signaling/New England Biolabs, Frankfurt, Germany), SHIP1 (N1), Fc $\gamma$ RIIb (N16), GAPDH (Santa Cruz Biotechnology, Santa Cruz, CA, USA), GFP (Rockland, Limerick, PA, USA), pFcyRIIb (LifeSpan BioScience, Seattle, WA, USA), and Tubulin (SigmaAldrich, St. Louis, MO, USA). Protein detection was performed using Fusion SL chemoluminescence detector (PeqLab, Erlangen, Germany).

\section{Mice and genotyping}

C567BL/6 FcyRIIb ${ }^{-/-}$mice were purchased from Taconic (Cologne, Germany). Genotyping was performed using Fc $\gamma$ RIIb_Neo_F:ATCGCCTTCTATCGCCTTCT; Fc $\gamma$ RIIb_

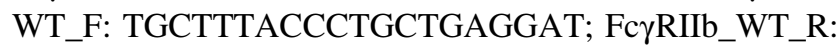
GGTCTGCTCCATTTGACACC enabling the identification of mutant FcyRIIb knockout (253 bp), wild-type (439 bp), or heterozygous (253 and $439 \mathrm{bp}$ ) mice. C567BL/6 wild-types were purchased from Janvier Labs (GenestSaint-Isle, France). Genotyping of SCLtTA/Bcr-Abl mice was described previously [26]. FVB/N CD45.2 recipients were bred in-house.

\section{BM transplantation}

BM cells from C567BL/6 Fc $\gamma \mathrm{RIIb}^{-/-}$, C567BL/6 FcyRIIb ${ }^{+/+}$ wild-type, and SCLtTA/Bcr-Abl mice were isolated 4 days after 5-FU injection. BM cells were retrovirally infected using MSCV-IRES-ev (empty vector)-GFP,
MSCV-IRES-Bcr-Abl-GFP, MSCV-LTR-miR30-SV40GFP-shRNA:scr, or MSCV-LTR-miR30-SV40-GFPshRNA:Fc $\gamma$ RIIb. Briefly, $1200 \mathrm{GFP}^{+}$Bcr-Abl-infected cells were transplanted together with $1 \times 10^{5}$ wild-type rescue BM cells into $11 \mathrm{~Gy}$ irritated C567BL/6 wild-type recipients. Recipients were sacrificed for analyses 15 days after transplantation. A total of $2.5 \times 10^{6}$ cells from LTR-miR30SV40-GFP-shRNA:scr (shRNA:scr) and MSCV-LTRmiR30-SV40-GFP-shRNA:Fc $\gamma R I I b \quad$ (shRNA:Fc $\gamma$ RIIb) non-fluorescence-activated cell sorting (FACS) sorted SCLtTA/Bcr-Abl BM cells were transplanted via tail vein injection into $10 \mathrm{~Gy}$ irradiated FVB/N CD45.2 mice. Mice were kept on cotrimoxazole (Ratiopharm, Ulm, Germany) for 1 week after transplantation.

\section{Ethics approval and consent to participate}

Application of human samples was approved by the local ethics board of the medical faculty RWTH Aachen (EK127/ 12, EK206/09). Informed consent was obtained from all patients. All animal experiments were approved by the local authorities (Landesamt für Natur, Umwelt und Verbraucherschutz NRW, LANUV Az. 8402.04.2013. A072).

\section{Flow cytometry analysis}

$\mathrm{BM}$ and spleen cells from recipient mice were isolated as described before [26]. Antibodies for immunophenotyping applied in this study are available in Supplementary Table S3.

\section{Apoptosis assay}

Apoptosis was analyzed using APC Annexin V Apoptosis Detection Kit (BioLegend) according to the manufacturer's protocol.

\section{Analysis of cell cycle phase}

Cell cycle analysis was performed using propidium iodide. Briefly, $2 \times 10^{6}$ cells were fixed with cold ethanol and subsequently incubated with $100 \mu \mathrm{g} / \mathrm{ml}$ RNAse (Qiagen, Hilden, Germany) and $50 \mu \mathrm{g} / \mathrm{ml}$ propidium iodide (SigmaAldrich) for $30 \mathrm{~min}$. Analysis was performed using FACS.

\section{Proliferation assay}

Cell proliferation was assessed via Trypan blue exclusion method. Cell count was analyzed every $24 \mathrm{~h}$ for 4 days. To analyze proliferation of CML, CD $34^{+}$CellTraceTM CFSE Kit (Thermo Fisher Scientific) was used according to the manufacturer's protocol. 


\section{Preparation and storage of reagents}

Imatinib (IM) (LC Laboratories, Woburn, MA, USA) was dissolved in dimethylsulfoxide (DMSO) and stored at $-20^{\circ} \mathrm{C}$ in stocks of $10 \mathrm{mM}$. Ibr (Selleckchem, Houston, TX, USA) was dissolved in DMSO at a stock concentration of $10 \mathrm{mM}$ and stored at $-80^{\circ} \mathrm{C}$.

\section{Statistical analysis}

Statistical analyses were performed using GraphPad Prism software (La Jolla, CA, USA). FACS data were analyzed using FlowJo (Version 10) or Kalzua (Version 1.3) software. Student's two-sided $t$ test or Mann-Whitney $U$ test were applied to compare the variability between two groups. Multiple group analyses were performed using one-way analysis of variance with Bonferroni's multiple comparison test. $P<0.05$ was considered as statistically significant. Error bars are given as standard derivation (s. d.).We performed neither blinding nor randomization within the animal experiments conducted in this study.

\section{Results}

\section{Malignant FcyRIlb upregulation is not targeted by TKI therapy}

We previously identified upregulation of Fc $\gamma$ RIIb

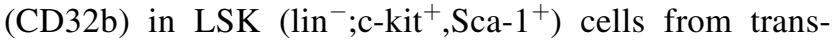
genic SCLtTA/Bcr-Abl CML-CP mice $(2.8$-fold, $p<0.05)$ by microarray analysis [26], and here we first confirmed upregulation of the receptor by real-time quantitative PCR (qRT-PCR) (Fc $\gamma$ RIIb) and FACS analysis (CD32b) in these malignant LSK cells (Fig. 1a). Next, we studied murine $\mathrm{C} 567 \mathrm{BL} / 6$ lin $^{-} \mathrm{BM}$ cells that were virally transduced to express Bcr-Abl. FcyRIIb messenger RNA (mRNA) and protein levels were again found to be significantly elevated in $\mathrm{Bcr}^{-\mathrm{Abl}^{+}}$cells vs. ev controls (Fig. 1b). Finally, we tested Fc $\gamma$ RIIb mRNA expression in CML vs. normal $\mathrm{CD} 34^{+}$cells and observed a 10.7 -fold increase in the human progenitor cell population (Fig. 1c). We proceeded to examine if TKI treatment could revert malignant FcyRIIb upregulation. CML cells from transgenic mice (Fig. 1d) and human CML cell lines K562 and KCL-22 (Fig. 1e) were treated with IM and this showed persisting Fc $\gamma$ RIIb expression; TKI treatment even enhanced Fc $\gamma$ RIIb mRNA expression in the latter cell line. As it has been shown that FcyRIIb expression is increased by the anti-inflammatory cytokine IL-4 [27], we analyzed publicly available microarray data for IL-4 expression in CML patients (GSE13159 and GSE13164, probe set id: 207539_s_at). IL-4 expression was significantly increased in CML vs. normal samples (Fig. 1f). In agreement, addition of IL-4 was able to increase FcyRIIb mRNA expression levels in the CML cell line KCL-22, and combined treatment with TKI could not antagonize elevated IL-4 expression, but even enhanced this effect (Supplementary Fig. S1), suggesting that TKI-persisting malignant upregulation could be mediated via altered cytokine levels in CML.

\section{FcyRllb depletion impairs leukemic stem and progenitor cell function}

In order to study the effect of receptor targeting in malignant cells, we next applied $\operatorname{lin}^{-} \mathrm{BM}$ cells from $\mathrm{Fc}_{\mathrm{RIIb}}{ }^{+/+}$and Fcy RIIb ${ }^{-/-}$mice that were virally infected to express Bcr-Abl or ev control. Colony-forming unit

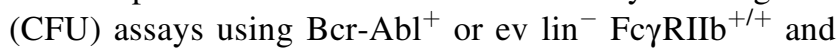
Fc $_{\text {RIIb }}{ }^{-1-}$ cells revealed significantly decreased colony numbers upon receptor depletion specifically in $\mathrm{Bcr}-\mathrm{Abl}^{+}$ cells (Fig. 2a). Moreover, CFU numbers were strongly reduced upon re-plating, suggesting reduced stem cell function of leukemic FcyRIIb ${ }^{-1-}$ cells (Fig. 2a). As lin $^{-}$ cells represent a rare cell population, we immortalized stem and progenitor cells using an estradiol regulated Hoxb8 approach [22]. We confirmed reduced clonogenic potential upon Fc $\gamma$ RIIb knockout likewise in these cells (Supplementary Fig. S2). Next, we analyzed cell proliferation from immortalized leukemic $\mathrm{Fc} \gamma \mathrm{RIIb}^{+/+}$vs. $\mathrm{Fc}_{\mathrm{RIIb}}{ }^{-1-}$ cells. FcyRIIb knockout significantly impaired proliferation in Bcr-Abl positive (Fig. 2b), but not Bcr-Abl-negative control cells (Supplementary Fig. S3). We proceeded to perform cell cycle analysis. Deficiency of Fc $\gamma$ RIIb increased the G0/G1 cell fraction, while $\mathrm{S}$ and G2/M phases were decreased (Fig. 2c). No cell cycle alterations were observed in ev control cells (Supplementary Fig. S4). Analyses of negative cell cycle regulator $\mathrm{p} 27^{\mathrm{Cip} 1}$ revealed increased protein expression in leukemic FcyRIIb knockout cells (Supplementary Fig. S5). Moreover, we observed increased RNA expression of the negative cell cycle regulators $\mathrm{p} 16^{\mathrm{Ink} 4 \mathrm{~A}}, \mathrm{p} 19^{\mathrm{Arf}}$, and $\mathrm{p} 27^{\mathrm{Cip} 1}$, but not $\mathrm{p} 21^{\mathrm{Cip} / \mathrm{Waf} 1}$, upon Fc $\gamma$ RIIb depletion in Bcr-Abl-positive cells (Supplementary Fig. S6). Taken together, these data show impaired malignant, but not normal stem and progenitor cell function upon Fc $\gamma \mathrm{RIIb}$ targeting.

\section{FcyRllb knockout or knockdown impairs CML development in vivo}

In order to study FcyRIIb function in vivo, we applied both a Bcr-Abl transduction model combined with genetic receptor depletion (Fig. 3a, model A) as well as strongly reduced Fc $\gamma$ RIIb expression mediated by shRNA using 

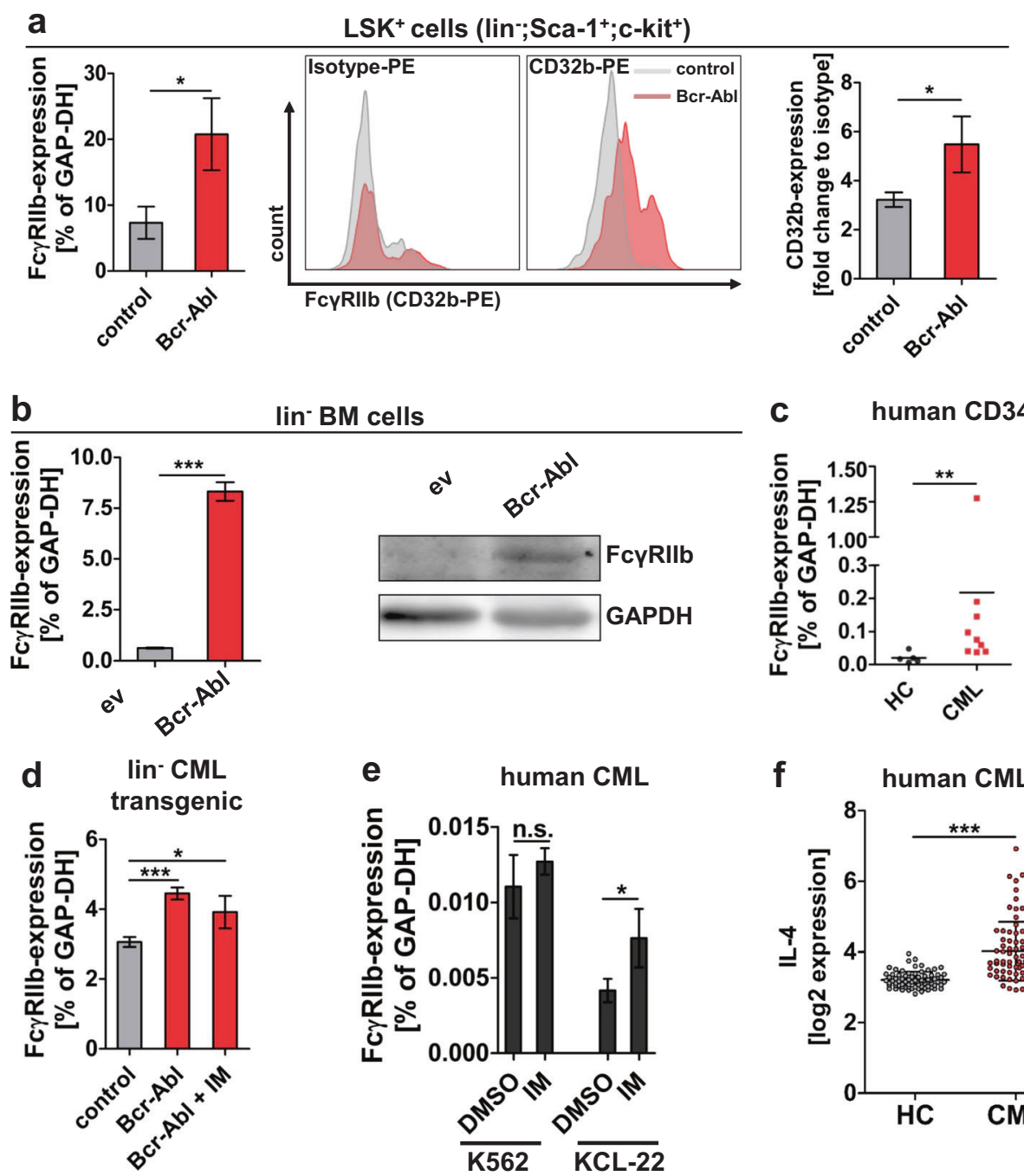

lin- BM cells
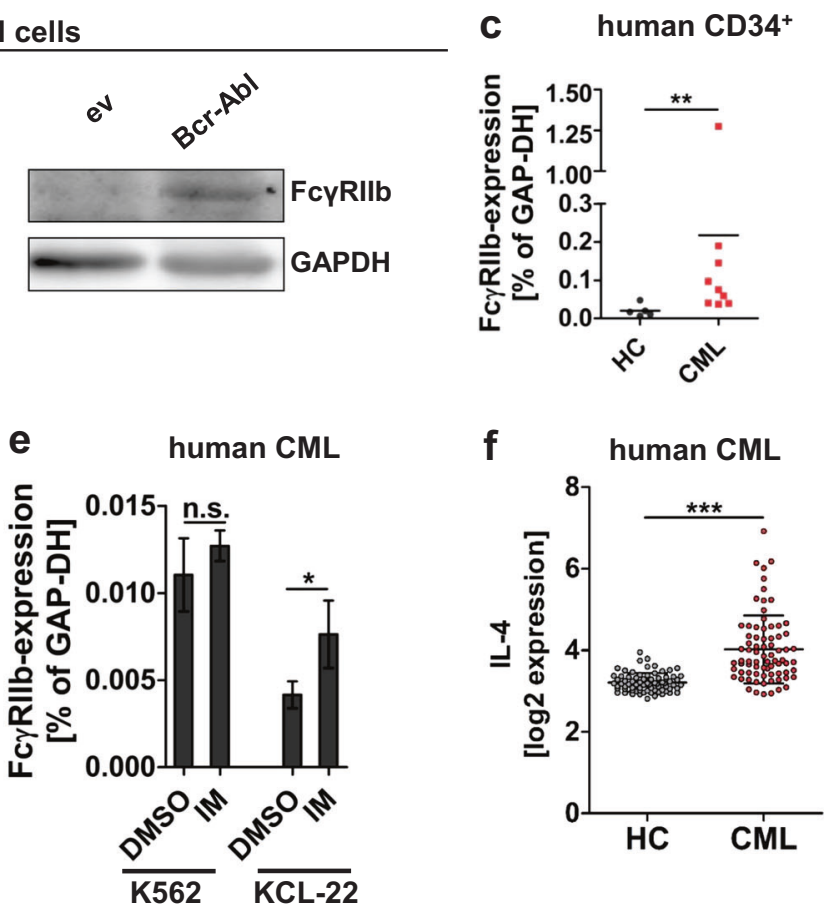

Fig. 1 FcyRIIb is upregulated in murine and human leukemic stem cells. a FcyRIIb RNA and protein expression were analyzed in $\mathrm{LSK}^{+}$cells $\left(\right.$lin $^{-} ; \mathrm{Sca}^{-1}{ }^{+} ; \mathrm{c}-\mathrm{kit}^{+}$) from transgenic SCLtTA/Bcr-Abl mice that had been induced to express Bcr-Abl vs. controls. FACS sorted $\mathrm{LSK}^{+}$from 3 weeks induced mice were analyzed using qRTPCR $(n=3 / 3)$. The cell surface expression of Fc $\gamma$ RIIb (CD32b) was assessed by FACS in mice that had been induced for 6 days $(n=3 / 3)$. b Lineage-depleted BM cells from C567B/L6 wild-type mice were virally transduced to express Bcr-Abl or empty vector (ev) control. Transduced cells were FACS sorted and analyzed for Fc $\gamma$ RIIb expression using qRT-PCR (left) and western blot analysis (right).

the transgenic SCLtTA/Bcr-Abl CML mouse model (Fig. 3a, model B). For the retroviral model, we transplanted $\mathrm{Fc}_{\mathrm{RII}} \mathrm{Rl}^{+/+}$or $\mathrm{Fc}_{\mathrm{RII}} \mathrm{RI}^{-1-} \mathrm{Bcr}-\mathrm{Abl}$-transduced $\mathrm{BM}$ cells into syngeneic C57BL/6 recipients. C57BL/6 mice receiving FcyRIlb ${ }^{-1-}$ Bcr-Abl-infected BM cells revealed a significantly reduced white blood cell compared to FcyRIIb ${ }^{+/+}$Bcr-Abl-transplanted recipients (Supplementary Fig. S7). Spleen weight of recipients was analyzed upon autopsy 15 days after transplantation revealing a significant reduction upon FcyRIIb depletion c Fc $\gamma$ RIIb mRNA expression was analyzed in $\mathrm{CD} 34^{+}$healthy control (HC) and CML patient samples $(n=5 / 9)$. d Lineage negative (lin $\left.{ }^{-}\right)$ $\mathrm{BM}$ cells from transgenic SCLtTA/Bcr-Abl mice vs. controls were analyzed for Fc $\gamma \mathrm{RIIb}$ expression before and after $2 \mu \mathrm{M}$ imatinib (IM) treatment for $18 \mathrm{~h}$. e K562 and KCL-22 cells were treated for $18 \mathrm{~h}$ with $5 \mu \mathrm{M}$ imatinib. f Public available microarray data from the leukemia MILE study (\#GSE13159 and \#GSE13164, probe set id: 207539_s_at) from BM biopsy of healthy control (HC) and CML patients at first diagnosis (CML) were analyzed for IL-4 expression $(n=73 / 76)$. Data are shown as mean \pm SD. $* p<0.05, * * p<0.001, * * * p<0.0001$, and n.s. not statistically significant.

(Fig. 3b). Vector-encoded GFP expression allowed for FACS analysis of Bcr-Abl-positive leukemic cells and revealed a reduction in total $\mathrm{BM}$ (4.19-fold) and spleen (2.62-fold) upon transplantation of $\mathrm{Fc}_{\mathrm{RIIb}}{ }^{-1-} \mathrm{Bcr}-\mathrm{Abl}$ compared to FcyRIIb ${ }^{+/+}$Bcr-Abl BM (Fig. 3c). Moreover, Fc $\gamma$ RIIb depletion reduced leukemic LSK cells by 2.19-fold (Fig. 3c). Next, we applied shRNA-mediated knockdown of FcyRIIb in vitro and in vivo using the SCLtTA/Bcr-Abl transgenic CML mouse model (Fig. 3a, model B). 


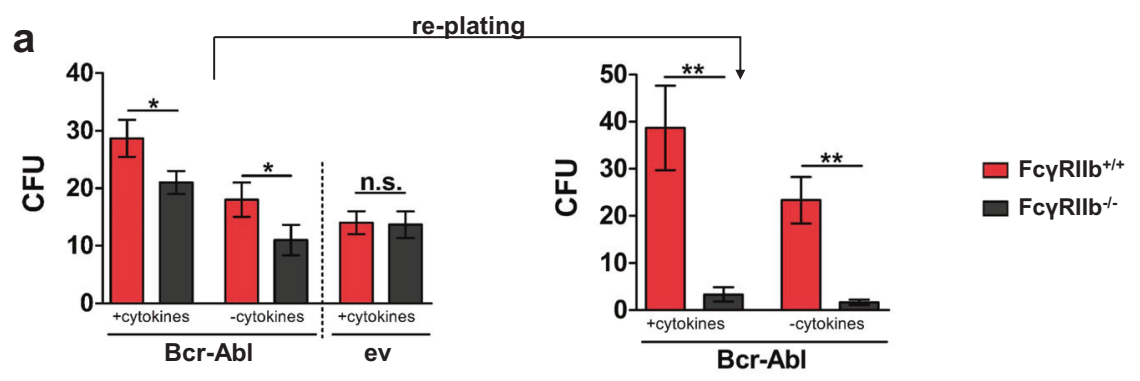

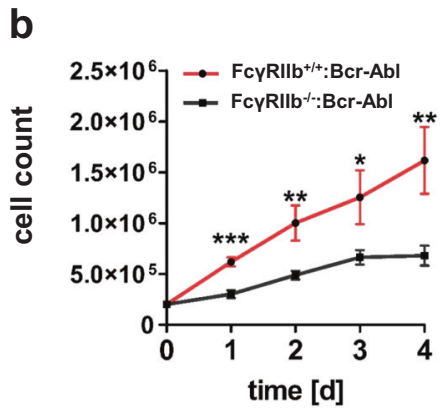

Fig. 2 FcyRIIb knockout reduces leukemic clonogenic potential and cell proliferation. a Bcr-Abl and ev (empty vector) infected lin ${ }^{-}$ $\mathrm{BM}$ cells from $\mathrm{Fc} \gamma \mathrm{RIIb}^{+/+}$and $\mathrm{Fc} \gamma \mathrm{RIIb}^{-1-}(1000$ cells/ml) were seeded in methylcellulose with or without cytokines. Numbers of colonies (colony-forming units, CFUs) were assessed after 7 days. Re-plating was performed using $1 \times 10^{4}$ cells. CFU numbers were counted after

Therefore, we first determined FcyRIIb knockdown efficiency on mRNA and protein level using different shRNAs (Supplementary Fig. S8). We identified shRNA\#3 that showed the strongest knockdown on protein expression and proceeded to reduce FcyRIIb expression using this shRNA; hereafter, named shRNA:Fc $\gamma$ RIIb. We first assessed proliferation of immortalized SCLtTA/Bcr-Abl BM cells and this was significantly impaired due to FcrRIIb knockdown (Supplementary Fig. S9). Likewise, clonogenic potential was drastically reduced upon Fc $\gamma$ RIIb knockdown (9.95-fold, Supplementary Fig. S10). We then transplanted shRNA:Fc $\gamma R I I b-$ or scr:shRNA-transduced control BM cells from SCLtTA/Bcr-Abl (CD45.1) into FVB/N (CD45.2) mice. Recipients were sacrificed 18 days after transplantation for analyses. Spleen weight was assessed upon autopsy and revealed a significant reduction in SCLtTA/Bcr-Abl shRNA:FcyRIIb-transplanted recipients compared to SCLtTA/Bcr-Abl shRNA:scr control mice (Fig. 3d). shRNA-infected cells were identified via the vector-encoded GFP expression and were reduced in BM (1.42-fold) and spleen (1.73-fold) upon Fc $\gamma$ RIIb knockdown (Fig. 3e). Next, we analyzed LSK cells in this model revealing a 1.38-fold decrease upon FcyRIIb targeting (Fig. 3e). These effects were less severe as compared to complete depletion of the receptor (Fig. 3c), likely reflecting residual FcyRIIb expression/activity in the knockdown vs. knockout model.

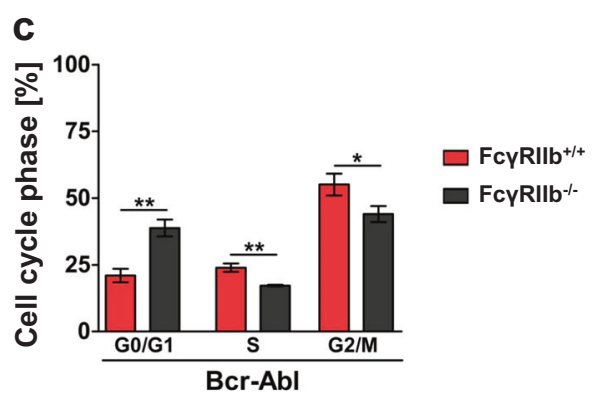

7 days. b Proliferation assay using Fc $\gamma \mathrm{RIIb}^{+/+}$and $\mathrm{Fc}_{\mathrm{RIIb}}{ }^{-/-} \mathrm{Bcr}-$ $\mathrm{Abl}^{+}$cells was performed using Trypan blue exclusion method. c Cell cycle was assessed in $\mathrm{Fc} \gamma \mathrm{RIIb}^{+/+}$and $\mathrm{Fc} \gamma \mathrm{RIIb}^{-1-} \mathrm{Bcr}-\mathrm{Abl}^{+}$cells. Data are shown as mean \pm SD. $n=3$, each, $* p<0.05$, ** $p<0.001$, ***p $p<$ 0.0001 , and n.s. not statistically significant.

\section{Malignant FcyRIlb signaling mediates BTK activation in leukemic progenitors}

We next studied the role of FcyRIIb-induced signal transduction employing, the immortalized $\mathrm{Fc}_{\mathrm{RIIb}}{ }^{-1-}$ and $\mathrm{Fc}_{\mathrm{RIIb}}{ }^{+/+}$progenitor cell model. As expected, pSTAT5 $^{\mathrm{Y} 694}$ and pCRKL $^{\mathrm{Y} 207}$ were present in leukemic FcyRIIb $^{-/-}$and FcyRIIb ${ }^{+/+}$Bcr-Abl positive cells (Fig. 4a). Interestingly, we identified reduced phosphorylation levels of Bruton's tyrosine kinase (BTK $\left.{ }^{\mathrm{Y} 223}\right), \mathrm{ERK} 1 / 2^{\mathrm{Y} 202 / 204}$ and p38 ${ }^{\mathrm{Y} 180 / 182}$ in leukemic cells that were depleted for Fc $\gamma \mathrm{RIIb}$. BTK total protein was likewise decreased. To analyze if reduced BTK signaling is truly FcyRIIb-dependent in BcrAbl-positive cells, we transduced $\mathrm{Fc} \gamma \mathrm{RIIb}^{-l-} \mathrm{BM}$ using an Fc $\gamma$ RIIb-encoding virus. Western blot analyses confirmed that pBTK was largely restored upon re-introduction of the receptor in FcyRIlb ${ }^{-1-}$ cells (Fig. 4b). As we observed reduced CFU potential upon FcyRIIb depletion in malignant cells (Fig. 2a), we proceeded to test the effect of FcyRIIb restoration also on the clonogenic potential. Upon reintegration of FcyRIIb into leukemic knockout cells, CFU numbers significantly increased again (Fig. 4c). Leukemic $\mathrm{Fc}_{\mathrm{RIIb}}{ }^{-1-}$ cells tended to form smaller and more diffuse colonies, compared to leukemic Fc $\gamma \mathrm{RIIb}^{+/+}$cells. This effect was dependent on FcyRIIb, as cells with restored receptor expression again formed colonies similar to leukemic FcyRIIb ${ }^{+/+}$cells (Supplementary Fig. S11). 
a

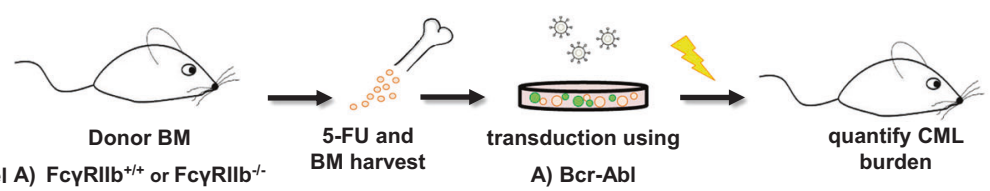

model A) FcyRIIb ${ }^{+/+}$or FcyRllb ${ }^{-1-}$

model B) SCLtTA/Bcr-Abl

B) shRNA:FcYRIIb
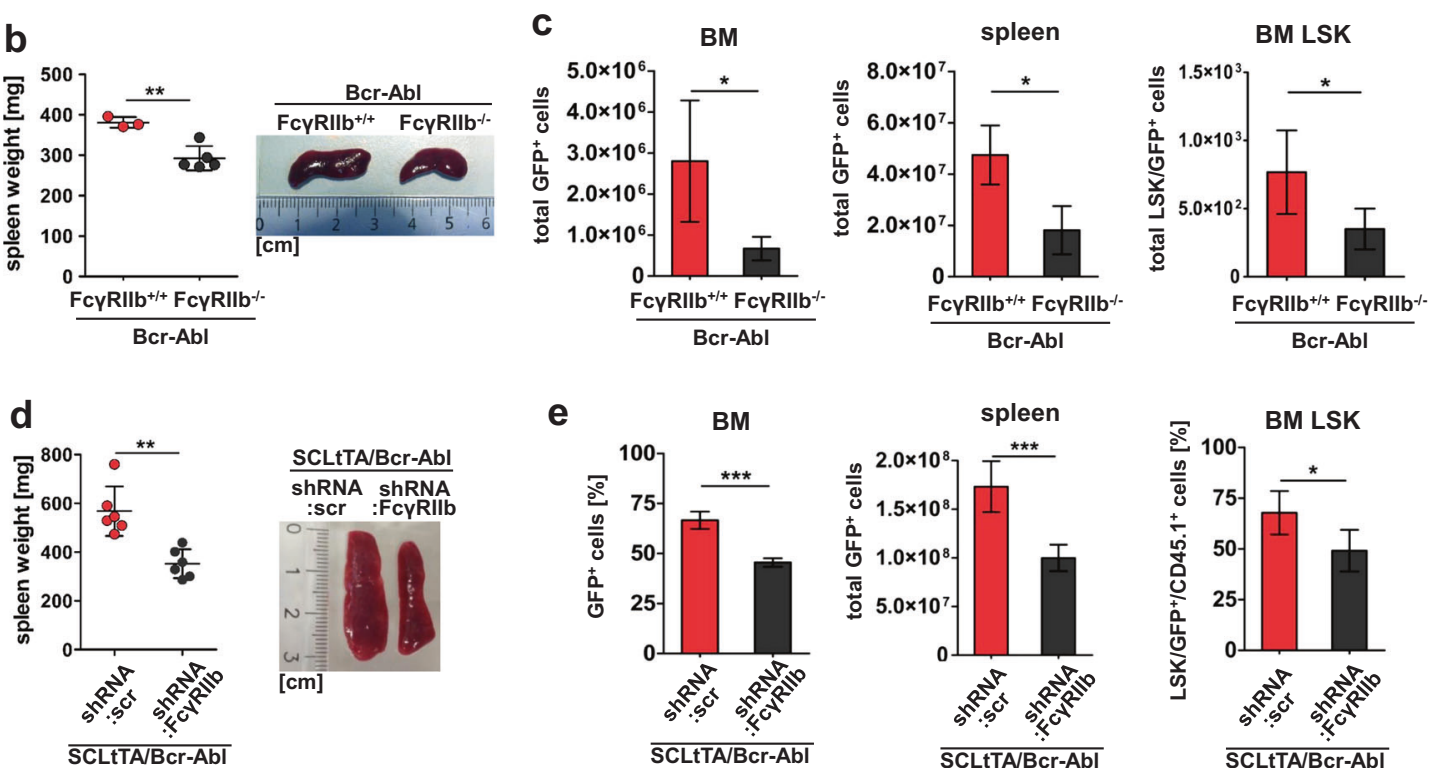

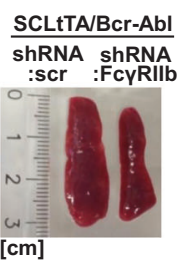

[cm]
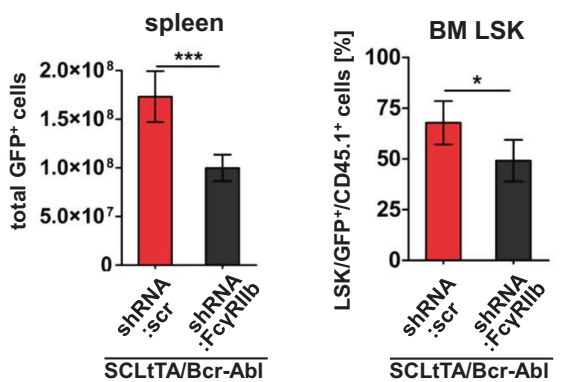

Fig. 3 Loss or reduction of FcyRIIb attenuates CML development and reduces leukemic LSK cells in vivo. a Schematic illustration of bone marrow transplantation approach using either $\mathrm{Fc} \gamma \mathrm{RIIb}^{+/+}$and $\mathrm{Fc}_{\mathrm{RIIb}}{ }^{-/-} \mathrm{C} 567 \mathrm{~B} / \mathrm{L} 6$ cells that were virally transduced to express Bcr-Abl (model A) or SCLtTA/Bcr-Abl FVB/N-derived BM cells that were transduced to express shRNA targeting Fc $\gamma$ RIIb (model B). b Spleen weight of transplanted recipients receiving $\mathrm{Fc}_{\mathrm{RIIb}} \mathrm{RI}^{+/}$:
$\operatorname{Bcr}-\mathrm{Abl}(n=3)$ or Fc $\gamma \mathrm{RIIb}^{-1-}: \mathrm{Bcr}-\mathrm{Abl}(n=5)$ BM cells. c Total leukemic $\mathrm{GFP}^{+}$cells in BM, spleen, and BM LSK compartment. d Spleen weight of FVB/N recipient mice transplanted with SCLtTA/ Bcr-Abl BM cells that were transduced with either shRNA:scr control or shRNA:Fc $\gamma$ RIIb. e Total leukemic $\mathrm{GFP}^{+}$cells in BM, spleen, and BM LSK compartment. Data are shown as mean \pm SD. $* p<0.05$ and $* * p<0.001$. a

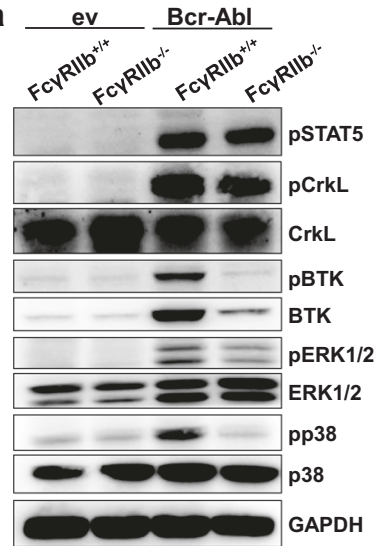

Fig. 4 FcyRIIb mediates malignant BTK activation in Bcr-Ablpositive cells. a Western blot analyses of immortalized Fc $\gamma \mathrm{RII}^{+/+}$ and $\mathrm{Fc} \gamma \mathrm{RIIb}^{-1-} \mathrm{Bcr}-\mathrm{Abl}$ and ev (empty vector) BM cells were performed using the indicated antibodies. b FcyRIIb was retrovirally introduced into $\mathrm{Fc} \gamma \mathrm{RIIb}^{-1-}: \mathrm{Bcr}-\mathrm{Abl}$ cells and protein lysates were
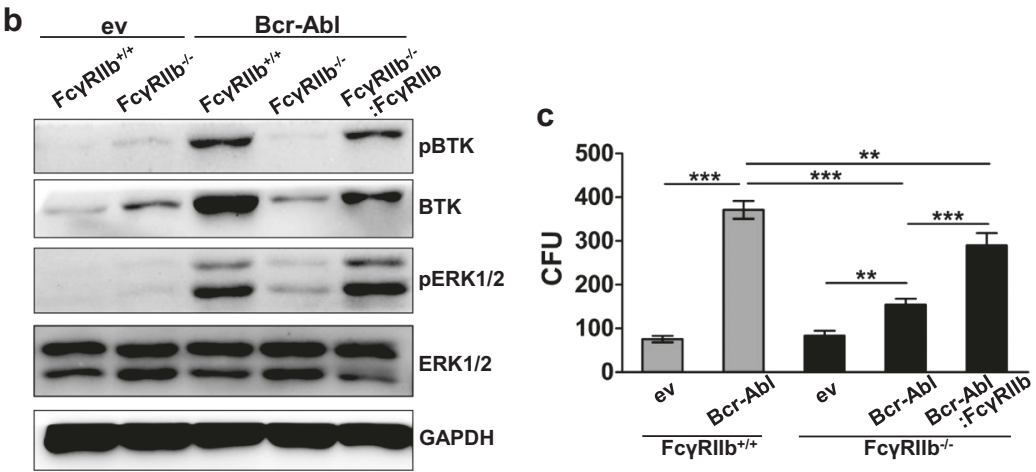

analyzed for BTK and ERK1/2 activation. $\mathbf{c}$ CFU assay using Fc $\gamma$ RIIb ${ }^{+/+}:$ev, Fc $\gamma R_{I I b}{ }^{-1-}:$ ev, Fc $\gamma$ RIIb $^{+/+}:$Bcr-Abl, Fc $\gamma R R^{\prime l b}{ }^{-/-}:$Bcr-Abl, or $\mathrm{Fc}_{\mathrm{RIIl}} \mathrm{R}^{-1-}: \mathrm{Bcr}-\mathrm{Abl}: \mathrm{Fc} \gamma \mathrm{RIIb}$ cells. Colony numbers were counted 7 days after seeding. Data are shown as mean \pm SD. $* * p<0.001$ and $* * * p<0.0001$. 


\section{Inhibition of Bcr-Abl combined with Ibr therapy reduces malignant potential and enhances apoptosis in nondividing CML-CP LSCs}

As we identified BTK as a downstream target of Fc $\gamma$ RIIb signaling in murine CML cells, we proceeded to study BTK phosphorylation in Bcr-Abl-positive K562 cells upon TKI treatment. As expected, Ibr treatment significantly decreased pBTK, but did not affect Bcr-Abl-induced signaling (Fig. 5a). In contrast, IM treatment abolished pBcr$\mathrm{Abl}$ and pSTAT5 levels, but only mildly reduced pBTK providing a rationale for dual targeting. As it has been reported that $\mathrm{Ibr}$ treatment reduces Bcr-Abl kinase activity in a murine progenitor cell line [28], we first treated 32D Bcr-Abl-expressing cells. In line with these results, we observed reduced Bcr-Abl phosphorylation upon increasing Ibr concentration in the murine cell line model (Supplementary Fig. S12). However, in human CML Ibr treatment had only mild effects on pBcr-Abl and this was not enhanced even by increasing concentrations up to $2.5 \mu \mathrm{M}$ (Fig. 5a). Next, we evaluated the effect of combined BTK and Bcr-Abl inhibition on MNCs and CML CD34 $4^{+}$cells. MNCs showed reduced CFU capacity upon IM and interestingly also upon Ibr treatment alone and administered together both drugs further reduced CFU numbers (Fig. 5b). Likewise, in CML CD34 ${ }^{+}$cells Ibr treatment significantly decreased colony formation compared to DMSO (Fig. 5c). Combined Ibr and IM therapy further reduced colony numbers compared to single TKI treatment in all samples tested (Fig. 5c). Protein expression analysis of CML CD34 ${ }^{+}$ cells revealed that Ibr inhibited BTK phosphorylation, while STAT5 activation was not affected, confirming that Bcr-Abl downstream signaling remained unaffected by Ibr. Also, IM treatment alone did not affect pBTK levels (Fig. 5d). Combined BTK and Bcr-Abl inhibition reduced proliferation of TKI-insensitive quiescent $\left(\mathrm{CFSE}^{\mathrm{Max}}\right) \mathrm{CD} 34^{+} \mathrm{CML}$ stem cells, yielding more cells with no or one division as compared to single IM treatment (Fig. 5e, Supplementary Figs. S13 + S14). However, apoptosis FACS of nondividing $\mathrm{CFSE}^{\mathrm{Max}} \mathrm{CD} 4^{+}$cells revealed a significant increase in the quiescent CML cell population (Fig. 5f, Supplementary Figs. S15 + S16), showing that combined treatment not only reduces the stem cell quality of CML cells, but also induces apoptosis in this therapy-resistant cell population. In conclusion, Ibr as an FDA-approved drug could therefore provide a novel therapeutic approach to overcome resistance in CML stem cells.

\section{Discussion}

A variety of clinical trials has revealed that TKI discontinuation in optimal responding patients allows for TFR in about half of this selected patient cohort. Thereby, a minimum of 2 years of continued therapy in deep molecular response seems to be beneficial [5, 29], but beyond that the effect on TFR is largely unchanged either by further therapy duration or the type of TKI tested [6, 30, 31], showing that Bcr-Abl-independent mechanisms must be targeted to increase TFR rates in patients, ideally using already approved drugs.

Here we show a critical function of the inhibitory ITIMreceptor Fc $\gamma$ RIIb in CML stem cell persistence and therapeutic targeting of malignant Fc $\gamma$ RIIb-mediated signaling enhanced TKI-mediated cell death in CML stem cells.

A positive role of ITIM-receptor signaling for HSC function in AML has previously been shown. The ITIMreceptor LIRB2 and its mouse homologous PirB are expressed on human and mouse HSCs, where their binding to angiopoietin-like proteins supports stem cell expansion. Genetic depletion of PirB enhanced differentiation and impaired MLL-AF9 AML development in vivo and LSC survival $[20,32]$. In ALL activation of the ITIM-receptor platelet endothelial cell adhesion molecule 1 (PECAM-1), CD300A, and LAIR1 has been shown to compensate for excessive signaling in B cells that is mediated through recruitment of the inhibitory phosphatases PTPN6 and INPP5D [33]. In CML the role of ITIM-receptor signaling has hardly been studied so far. Using human cell lines, the ITIM-receptor PECAM-1 was found to antagonize IMinduced apoptosis [34], but genetic depletion of PECAM-1 in a retroviral model of CML-like disease showed no effect on CML myeloid progenitor viability or clonogenic potential in vitro [33].

Here we at first identified TKI-resistant FcyRIIb upregulation in murine and human CML stem and progenitor cells. Cytokines such as IL-4 or IL-10 are known to induce Fc $\gamma$ RIIb upregulation [27, 35] and, indeed, we could confirm IL-4-mediated Fc $\gamma$ RIIb upregulation in malignant cells that was not decreased upon TKI treatment. Concordantly, expression of the IL-4 receptor alpha chain was significantly upregulated (2.23-fold, $p=0.0062$, data not shown) in CML vs. normal LSK cells in our microarray analysis of the transgenic SCLtTA/Bcr-Abl mouse model [26], which likewise showed FcyRIIb upregulation. IL-4 was previously found to be increased in the plasma of CML patients [36] and corresponding to this IL-4 secretion by the malignant clone has been shown for K562 and BA/F3:Bcr-Abl CML cells, where IL-4 secretion antagonized IM-induced apoptosis [37]. Moreover, downregulation of IL-4 is evident in unfractionated $\mathrm{BM}$ or $\mathrm{pB}$ leukocytes from cytogenetic responders vs. non-responders [38] (Supplementary Fig. S17), and taken together, these data suggest that IL-4 could be a candidate for permitting TKI-persisting Fc $\gamma$ RIIb upregulation. Further analyses correlating IL-4 serum levels with pBTK ideally in LSCs from patients who remain in or 


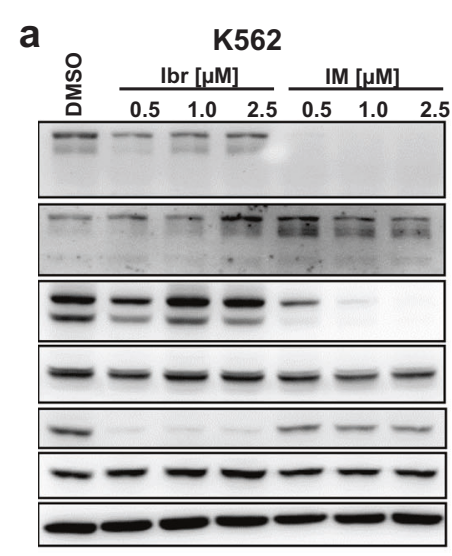

C

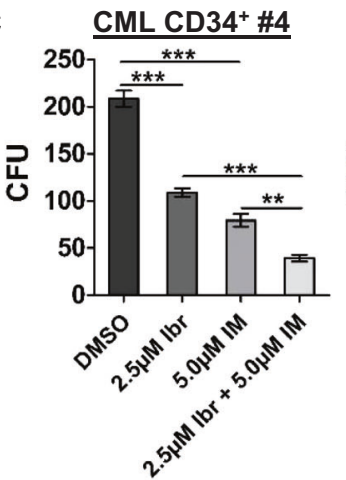

b
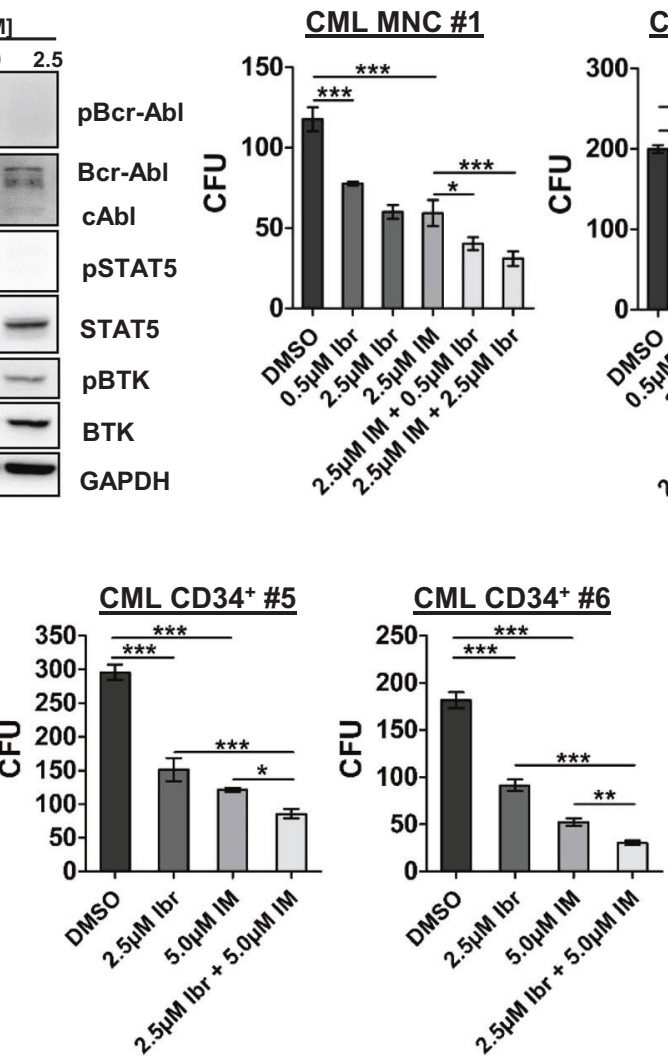

e

\section{CD $34^{+} \# 4$}

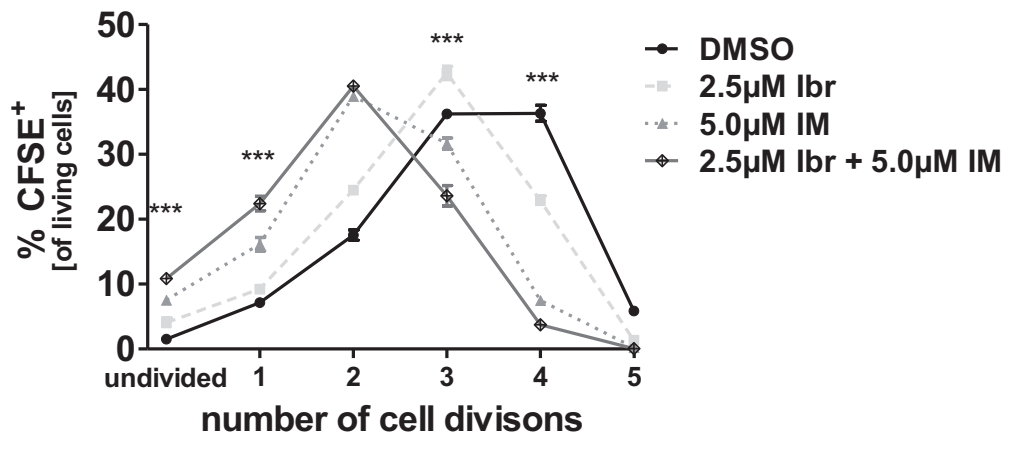

ML MNC \#2
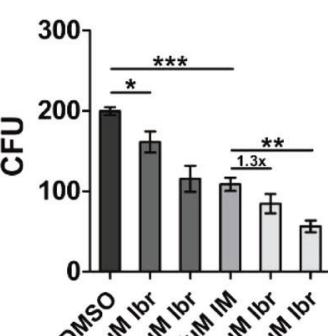

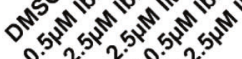

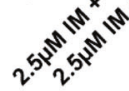
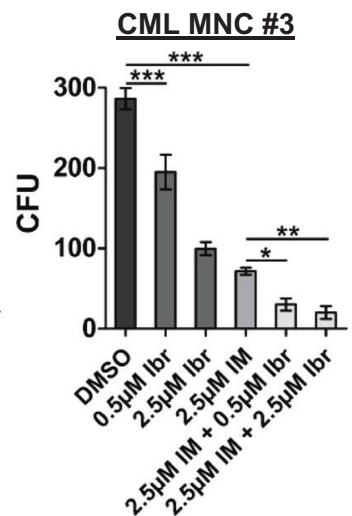
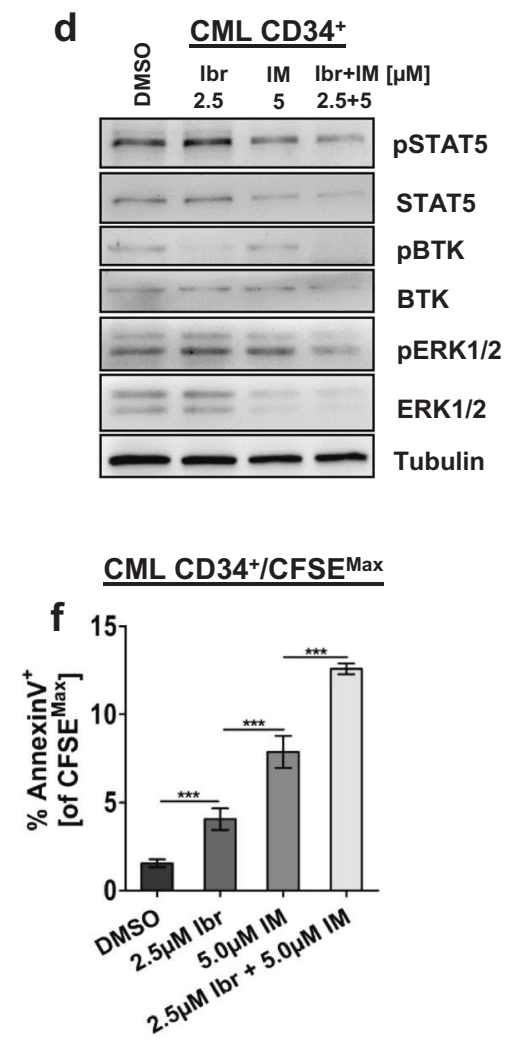

g

FcyRllb

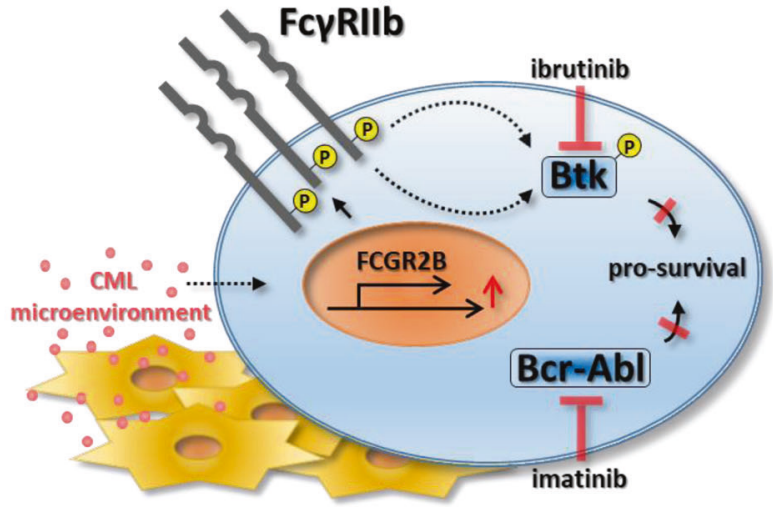


4 Fig. 5 Combined inhibition of Bcr-Abl and BTK impairs clonogenic potential, reduces proliferation, and enhances apoptosis in nondividing LSCs. a K562 cells were treated with increasing concentrations of Ibr (Ibrutinib, 0.5-2.5 $\mu \mathrm{M}$ ) or IM (Imatinib, 0.5-2.5 $\mu \mathrm{M}$ ) for $18 \mathrm{~h}$. Subsequently, protein lysates were analyzed for pBcr-Abl, pSTAT5, pBTK, Bcr-Abl, STAT5, BTK, and GAPDH. b Primary CML MNCs $(10,000$ cells $/ \mathrm{ml})$ were treated for $48 \mathrm{~h}(\mathbf{c})$ and CML $\mathrm{CD}^{+}{ }^{+}$cells $(1000$ cells $/ \mathrm{ml})$ for $72 \mathrm{~h}$ with $\mathrm{Ibr}(0.5 \mu \mathrm{M}, 2.5 \mu \mathrm{M})$, IM $(2.5 \mu \mathrm{M}, 5.0 \mu \mathrm{M})$, or the combination of both drugs. Cells were resuspended and plated using methylcellulose-containing cytokines. CFU numbers were counted after 7 days $\left(n=3\right.$, each). d CML CD $34^{+}$ cells were treated for $72 \mathrm{~h}$ with $2.5 \mu \mathrm{M} \mathrm{Ibr}, 5.0 \mu \mathrm{M} \mathrm{IM}$, and the combination of both drugs. Protein lysates were analyzed for pSTAT5, pBTK, pERK1/2, STAT5, BTK, and ERK1/2. e Evaluation of cell divisions in CML CD34 ${ }^{+}$cells upon treatment using CFSE combined with FACS analyses. For a clear presentation, the level of significance is given for Ibr + IM vs. IM only. f Annexin $\mathrm{V}^{+}$staining of undivided CFSE $^{\mathrm{Max}}$ cells in treated CML CD $34^{+}$cells. g Proposed mechanism: elevated FcyRIIb expression in malignant cells persists despite BCR$\mathrm{ABL}$ inhibition and this could be mediated via inflammatory cytokines in the CML microenvironment. FcyRIIb activity results in increased BTK expression and phosphorylation and dual targeting of BCR-ABL and BTK activity induces apoptosis in LSCs. Data are shown as mean \pm SD. $* p<0.05, * * p<0.001$, $* * * p<0.0001$, and n.s. not statistically significant.

not remain in TFR after TKI discontinuation would (1) further underline the significance of pBTK in LSC resistance and (2) could unravel the potential of IL-4 or pBTK being a biomarker that would allow predicting the outcome of TKI discontinuation.

By using Fc $\gamma \mathrm{RIIb}^{-1-}$ BM cells, we identified markedly decreased clonogenic potential, particularly apparent upon serial re-plating, suggesting that primitive hematopoietic cells are notably affected by Fc $\gamma$ RIIb targeting. Colonies that were generated by Bcr-Abl-positive $\mathrm{Fc}_{\mathrm{RIIb}}{ }^{-/}$cells were less compact and more diffuse compared to Bcr-Ablpositive $\mathrm{Fc}_{\mathrm{RIIb}}{ }^{+/+}$cells, and more diffuse colonies indicate an increased differentiation potential [39]. Decreased CFU potential and colony morphology could be largely rescued by reconstituting FcyRIIb expression. Transplantation of $\mathrm{Fc} \gamma \mathrm{RIIb}^{-/-} \mathrm{BM}$ cells into recipient mice impaired the CML phenotype, including a reduction of leukemic LSK cells using a retroviral and transgenic CML mouse model. Reduced malignant cell expansion is in line with decreased proliferation in malignant FcyRIIb-depleted or SCLtTA/Bcr-Abl Fc $\gamma$ RIIb shRNA-transduced cells. Moreover, we observed a strong increase in negative cell cycle regulators $\mathrm{p} 16^{\text {Ink4A }}, \mathrm{p} 19^{\text {Arf }}$, and p $27^{\text {Cip1 }}$ in leukemic Fc $\gamma$ RIIb ${ }^{-I-}$ cells. These effects were only evident in malignant, but not in Bcr-Abl-negative Fc $\gamma \mathrm{RIIb}^{-1-}$ cells. Activation of cell cycle checkpoint molecules due to ITIM-receptor knockout was previously reported in Bcr-Abl-positive pre-B cells [33]. In this model, ITIM-receptor depletion resulted similarly in cell cycle arrest and complete loss of CFU potential.

The FcyRIIb ITIM motif can be phosphorylated by SRC family kinase LYN [18]. It has been shown that
LYN-mediated FcyRIIb phosphorylation results preferentially in recruitment of SHIP1 (INPP5D) in vivo [40-42]. SHIP1 then hydrolyses 5 -phosphate of phosphatidylinositol-3,4,5trisphosphate, which alters the interaction of various signaling molecules with the plasma membrane, thereby affecting intracellular signal transduction. In contrast to published data where SHIP1-dependent Fc $\gamma$ RIIb signaling attenuates ERK1/2 activation [43], we observed reduced ERK1/2 phosphorylation due to FcyRIIb deficiency in leukemic cells. Similarly, we observed diminished BTK activation due to FcyRIlb knockout in malignant cells that could be restored upon rescued FcyRIIb expression. Global phosphotyrosine profiling previously identified an activated BTK-derived peptide in Bcr-Ablexpressing BA/F3 cells [44]. Applying the BTK inhibitor LFM-A13 on Bcr-Abl ${ }^{+}$cell lines reduced cell viability similar to IM [45]. A further report studying BTK function by pharmacologic inhibition using PC-005 to inhibit BTK likewise showed reduced growth of a $\mathrm{Bcr}^{-\mathrm{Abl}^{+}}$murine $\mathrm{BA} / \mathrm{F} 3$ lymphoid progenitor cell line, but this was associated with offdrug target effects reducing Bcr-Abl kinase activity [28]. We have observed similar reduction of pBcr-Abl upon BTK inhibition using $\mathrm{Ibr}$ in murine Bcr-Abl-expressing 32D cell line. However, in human K562 CML cells as well as patientderived CML CD34 ${ }^{+}$cells, no drastically altered Bcr-Abl or STAT5 phosphorylation was evident upon Ibr treatment.

Our data show elevated BTK protein expression in BcrAbl-positive transgenic cells, in the presence of FcyRIIb. Upon depletion of the receptor, BTK protein significantly decreases in malignant cells and this is partially restored by reconstituting FcyRIIb expression. Expression of total ERK or p38 protein is not affected by Fc $\gamma$ RIIb depletion. Despite, phosphorylation of these targets is Bcr-Abl dependent, as expected. To this end, it has been shown that inhibition of Bcr-Abl kinase activity by IM significantly decreases phosphorylation of ERK1/2 or p38, while total protein remained unaffected [46]. Moreover, in a model of doxycycline-regulated Bcr-Abl expression, reversion of Bcr-Abl altered the level of ERK1/2 or p38 phosphorylation, while the total protein did not change [47]. However, the underlying mechanism that results in BTK protein reduction upon FcyRIIb depletion in malignant cells is unclear. It has been shown that BTK can induce its own transcription by a nuclear factor- $\mathrm{\kappa B}(\mathrm{NF}-\mathrm{\kappa B})$-dependent mechanism [48]. In addition, the Fc $\gamma$ RIIb itself is induced

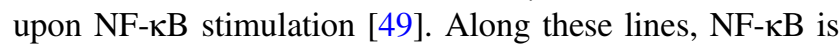
activated in CML cells despite Bcr-Abl inhibition, downstream of, for example, IL-1 [15] or TNF signaling [50]. Moreover, activation of NF- $\mathrm{KB}$ downstream of IL-4 has been shown [51] and our data already suggest that IL-4 is involved in TKI-resistant FcyRIIb upregulation (Fig. If and Supplementary Fig. S1). Interestingly, the deletion of the $\gamma$ chain subunit in $F c \gamma R$ knockout mice blocked NF- $\kappa B$ activation in these mice [52]. Therefore, it is tempting to 
speculate that BTK protein could be upregulated via NF-kB in malignant FcyRIIb-expressing cells and it would be highly interesting to study the effect of FcyRIIb depletion on NF- $\kappa \mathrm{B}-$ mediated BTK activation in our model.

Simultaneous administration of Ibr and IM was superior in reducing the clonogenic potential of CML-CP patientderived $\mathrm{MNCs}$ and primitive $\mathrm{CD} 34^{+}$cells compared to single TKI application. Moreover, Bcr-Abl inhibition combined with Ibr treatment increased apoptosis in quiescent CML-CP LSCs.

The BTK inhibitor Ibr is already approved for the treatment of CLL and mantle cell lymphoma and was further effective in pre-clinical AML studies, multiple myeloma, and pre-BCR B-ALL [53-55]. It has to be considered that Ibr therapy is associated with considerable toxicity, including atrial fibrillation, bleeding, neutropenia, and infections, as well as gastrointestinal symptoms [56-58]. Careful selection of patients and dosing will be important for phase I and II combination trials. In addition, given the current cost of Ibr, the potential treatment regime should be carefully elaborated. We could envision short-term Ibr treatment in patients who are already eligible for TKI discontinuation due to deep molecular remission. In these patients, Ibr could either replace Bcr-Abl-directed TKI therapy or be administered together with Bcr-Abl inhibition for a defined period. Molecular monitoring in close intervals during and after therapy could then unravel if TFR rate could be increased using this strategy. If toxicity is acceptable, the cost at long term would be reduced if a higher rate of patients will obtain TFR.

This study shows that BTK inhibition by the FDAapproved drug Ibr significantly affects LSC survival in CML and hence targeting the Bcr-Abl-FcyRIIb-BTK axis is a novel therapeutic strategy contributing to the eradication of therapy-resistant LSCs.

Acknowledgements We thank Kristina Feldberg and Julia Plum for excellent technical assistance. This work was financially supported by the DFG (Deutsche Forschungsgemeinschaft, GZ: SCHE 1938/1-1, grant holder: MS) and by the Medical faculty of the RWTH Aachen (START 691706, grant holder: MS). We also thank Hans Häcker for providing the MSCV-ERBDH-HoxB8-Neo plasmid. Open access funding provided by Projekt DEAL.

Author contributions OP performed experiments, analyzed the data, designed research, and wrote the manuscript. SL, MKK, and CW performed experiments and wrote the manuscript. T.M., I.G.C., analyzed the data. MH, SL, TB, NC, MC, THB, and SK contributed research material, analyzed the data, and wrote the manuscript. MS designed research, performed experiments, analyzed the data, and wrote the manuscript. All authors approved the final version of the manuscript.

\section{Compliance with ethical standards}

Conflict of interest SK reports having served on Advisory Boards for Pfizer, Incyte/Ariad, Novartis, AOP, BMS, and CTI; Honoraria:
Novartis, BMS, Pfizer, Incyte/Ariad, Shire, Janssen; Scientific Research Support: Novartis Foundation, BMS, Novartis; Others: Alexion. All the other authors declare that they have no conflict interest.

Publisher's note Springer Nature remains neutral with regard to jurisdictional claims in published maps and institutional affiliations.

Open Access This article is licensed under a Creative Commons Attribution 4.0 International License, which permits use, sharing, adaptation, distribution and reproduction in any medium or format, as long as you give appropriate credit to the original author(s) and the source, provide a link to the Creative Commons license, and indicate if changes were made. The images or other third party material in this article are included in the article's Creative Commons license, unless indicated otherwise in a credit line to the material. If material is not included in the article's Creative Commons license and your intended use is not permitted by statutory regulation or exceeds the permitted use, you will need to obtain permission directly from the copyright holder. To view a copy of this license, visit http://creativecommons. org/licenses/by/4.0/.

\section{References}

1. Skorski T, Kanakaraj P, Nieborowska-Skorska M, Ratajczak MZ, Wen SC, Zon G, et al. Phosphatidylinositol-3 kinase activity is regulated by $\mathrm{BCR} / \mathrm{ABL}$ and is required for the growth of Philadelphia chromosome-positive cells. Blood. 1995;86:726-36.

2. Morgan MA, Dolp O, Reuter CW. Cell-cycle-dependent activation of mitogen-activated protein kinase kinase (MEK-1/2) in myeloid leukemia cell lines and induction of growth inhibition and apoptosis by inhibitors of RAS signaling. Blood. 2001;97:1823-34.

3. Zhang B, Li M, McDonald T, Holyoake TL, Moon RT, Campana D, et al. Microenvironmental protection of CML stem and progenitor cells from tyrosine kinase inhibitors through $\mathrm{N}$ cadherin and Wnt-beta-catenin signaling. Blood. 2013;121: 1824-38.

4. Druker BJ, Talpaz M, Resta DJ, Peng B, Buchdunger E, Ford JM, et al. Efficacy and safety of a specific inhibitor of the BCR-ABL tyrosine kinase in chronic myeloid leukemia. N Engl J Med. 2001;344:1031-7.

5. Mahon FX, Rea D, Guilhot J, Guilhot F, Huguet F, Nicolini F, et al. Discontinuation of imatinib in patients with chronic myeloid leukaemia who have maintained complete molecular remission for at least 2 years: the prospective, multicentre Stop Imatinib (STIM) trial. Lancet Oncol. 2010;11:1029-35.

6. Rea D, Nicolini FE, Tulliez M, Guilhot F, Guilhot J, GuerciBresler A, et al. Discontinuation of dasatinib or nilotinib in chronic myeloid leukemia: interim analysis of the STOP 2G-TKI study. Blood. 2017;129:846-54.

7. Ross DM, Masszi T, Gomez Casares MT, Hellmann A, Stentoft J, Conneally E, et al. Durable treatment-free remission in patients with chronic myeloid leukemia in chronic phase following frontline nilotinib: 96-week update of the ENESTfreedom study. J Cancer Res Clin Oncol. 2018;144:945-54.

8. Corbin AS, Agarwal A, Loriaux M, Cortes J, Deininger MW, Druker BJ. Human chronic myeloid leukemia stem cells are insensitive to imatinib despite inhibition of BCR-ABL activity. J Clin Invest. 2011;121:396-409.

9. Hamilton A, Helgason GV, Schemionek M, Zhang B, Myssina S, Allan EK, et al. Chronic myeloid leukemia stem cells are not dependent on Bcr-Abl kinase activity for their survival. Blood. 2012;119:1501-10. 
10. Copland M, Hamilton A, Elrick LJ, Baird JW, Allan EK, Jordanides N, et al. Dasatinib (BMS-354825) targets an earlier progenitor population than imatinib in primary CML but does not eliminate the quiescent fraction. Blood. 2006;107:4532-9.

11. Jorgensen HG, Allan EK, Jordanides NE, Mountford JC, Holyoake TL. Nilotinib exerts equipotent antiproliferative effects to imatinib and does not induce apoptosis in CD34+ CML cells. Blood. 2007;109:4016-9.

12. Kuepper MK, Butow M, Herrmann O, Ziemons J, Chatain N, Maurer A, et al. Stem cell persistence in CML is mediated by extrinsically activated JAK1-STAT3 signaling. Leukemia. 2019;33:1964-77.

13. Prost S, Relouzat F, Spentchian M, Ouzegdouh Y, Saliba J, Massonnet G, et al. Erosion of the chronic myeloid leukaemia stem cell pool by PPARgamma agonists. Nature. 2015;525:380-3.

14. Abraham SA, Hopcroft LE, Carrick E, Drotar ME, Dunn K, Williamson AJ, et al. Dual targeting of p53 and c-MYC selectively eliminates leukaemic stem cells. Nature. 2016;534:341-6.

15. Zhang B, Chu S, Agarwal P, Campbell VL, Hopcroft L, Jorgensen $\mathrm{HG}$, et al. Inhibition of interleukin-1 signaling enhances elimination of tyrosine kinase inhibitor-treated CML stem cells. Blood. 2016;128:2671-82.

16. Kuntz EM, Baquero P, Michie AM, Dunn K, Tardito S, Holyoake TL, et al. Targeting mitochondrial oxidative phosphorylation eradicates therapy-resistant chronic myeloid leukemia stem cells. Nat Med. 2017;23:1234-40.

17. Ravetch JV, Lanier LL. Immune inhibitory receptors. Science. 2000;290:84-89.

18. Malbec O, Fong DC, Turner M, Tybulewicz VL, Cambier JC, Fridman WH, et al. Fc epsilon receptor I-associated lyn-dependent phosphorylation of $\mathrm{Fc}$ gamma receptor IIB during negative regulation of mast cell activation. J Immunol. 1998;160:1647-58.

19. Iwasaki M, Kuwata T, Yamazaki Y, Jenkins NA, Copeland NG, Osato M, et al. Identification of cooperative genes for NUP98HOXA9 in myeloid leukemogenesis using a mouse model. Blood. 2005;105:784-93.

20. Zheng J, Umikawa M, Cui C, Li J, Chen X, Zhang C, et al. Inhibitory receptors bind ANGPTLs and support blood stem cells and leukaemia development. Nature. 2012;485:656-60.

21. Kang X, Lu Z, Cui C, Deng M, Fan Y, Dong B, et al. The ITIMcontaining receptor LAIR1 is essential for acute myeloid leukaemia development. Nat Cell Biol. 2015;17:665-77.

22. Wang GG, Calvo KR, Pasillas MP, Sykes DB, Hacker H, Kamps MP. Quantitative production of macrophages or neutrophils ex vivo using conditional Hoxb8. Nat Methods. 2006;3:287-93.

23. Schemionek M, Herrmann O, Reher MM, Chatain N, Schubert C, Costa IG, et al. Mtss1 is a critical epigenetically regulated tumor suppressor in CML. Leukemia. 2016;30:823-32.

24. Elling C, Erben P, Walz C, Frickenhaus M, Schemionek M, Stehling $\mathrm{M}$, et al. Novel imatinib-sensitive PDGFRA-activating point mutations in hypereosinophilic syndrome induce growth factor independence and leukemia-like disease. Blood. 2011;117: 2935-43.

25. Schemionek M, Spieker T, Kerstiens L, Elling C, Essers M, Trumpp A, et al. Leukemic spleen cells are more potent than bone marrow-derived cells in a transgenic mouse model of CML. Leukemia. 2012;26:1030-7.

26. Schemionek M, Elling C, Steidl U, Baumer N, Hamilton A, Spieker T, et al. BCR-ABL enhances differentiation of long-term repopulating hematopoietic stem cells. Blood. 2010;115:3185-95.

27. Pricop L, Redecha P, Teillaud JL, Frey J, Fridman WH, SautesFridman $\mathrm{C}$, et al. Differential modulation of stimulatory and inhibitory Fc gamma receptors on human monocytes by Th1 and Th2 cytokines. J Immunol. 2001;166:531-7.

28. MacPartlin M, Smith AM, Druker BJ, Honigberg LA, Deininger MW. Bruton's tyrosine kinase is not essential for Bcr-Abl- mediated transformation of lymphoid or myeloid cells. Leukemia. 2008;22:1354-60.

29. Takahashi N, Kyo T, Maeda Y, Sugihara T, Usuki K, Kawaguchi $\mathrm{T}$, et al. Discontinuation of imatinib in Japanese patients with chronic myeloid leukemia. Haematologica. 2012;97:903-6.

30. Rousselot P, Charbonnier A, Cony-Makhoul P, Agape P, Nicolini $\mathrm{FE}$, Varet $\mathrm{B}$, et al. Loss of major molecular response as a trigger for restarting tyrosine kinase inhibitor therapy in patients with chronic-phase chronic myelogenous leukemia who have stopped imatinib after durable undetectable disease. J Clin Oncol. 2014;32:424-30.

31. Saussele S, Richter J, Guilhot J, Gruber FX, Hjorth-Hansen H, Almeida A, et al. Discontinuation of tyrosine kinase inhibitor therapy in chronic myeloid leukaemia (EURO-SKI): a prespecified interim analysis of a prospective, multicentre, non-randomised, trial. Lancet Oncol. 2018;19:747-57.

32. Kang X, Cui C, Wang C, Wu G, Chen H, Lu Z, et al. CAMKs support development of acute myeloid leukemia. J Hematol Oncol. 2018;11:30.

33. Chen Z, Shojaee S, Buchner M, Geng H, Lee JW, Klemm L, et al. Signalling thresholds and negative B-cell selection in acute lymphoblastic leukaemia. Nature. 2015;521:357-61.

34. Wu N, Kurosu T, Oshikawa G, Nagao T, Miura O. PECAM-1 is involved in BCR/ABL signaling and may downregulate imatinibinduced apoptosis of Philadelphia chromosome-positive leukemia cells. Int J Oncol. 2013;42:419-28.

35. Joshi T, Ganesan LP, Cao X, Tridandapani S. Molecular analysis of expression and function of hFcgammaRIIbl and b2 isoforms in myeloid cells. Mol Immunol. 2006;43:839-50.

36. Nievergall E, Reynolds J, Kok CH, Watkins DB, Biondo M, Busfield SJ, et al. TGF-alpha and IL-6 plasma levels selectively identify CML patients who fail to achieve an early molecular response or progress in the first year of therapy. Leukemia. 2016;30:1263-72.

37. Gregory MA, Phang TL, Neviani P, Alvarez-Calderon F, Eide CA, O'Hare T, et al. Wnt/Ca ${ }^{2+} / \mathrm{NFAT}$ signaling maintains survival of $\mathrm{Ph}+$ leukemia cells upon inhibition of Bcr-Abl. Cancer Cell. 2010;18:74-87.

38. Crossman LC, Mori M, Hsieh YC, Lange T, Paschka P, Harrington $\mathrm{CA}$, et al. In chronic myeloid leukemia white cells from cytogenetic responders and non-responders to imatinib have very similar gene expression signatures. Haematologica. 2005;90: 459-64.

39. Lavau C, Szilvassy SJ, Slany R, Cleary ML. Immortalization and leukemic transformation of a myelomonocytic precursor by retrovirally transduced HRX-ENL. EMBO J. 1997; 16:4226-37.

40. Ono M, Bolland S, Tempst P, Ravetch JV. Role of the inositol phosphatase SHIP in negative regulation of the immune system by the receptor Fc(gamma)RIIB. Nature. 1996;383:263-6.

41. Bruhns P, Vely F, Malbec O, Fridman WH, Vivier E, Daeron M. Molecular basis of the recruitment of the $\mathrm{SH} 2$ domain-containing inositol 5-phosphatases SHIP1 and SHIP2 by fcgamma RIIB. J Biol Chem. 2000;275:37357-64.

42. Lesourne R, Bruhns P, Fridman WH, Daeron M. Insufficient phosphorylation prevents fc gamma RIIB from recruiting the $\mathrm{SH} 2$ domain-containing protein-tyrosine phosphatase SHP-1. J Biol Chem. 2001;276:6327-36.

43. Nakamura K, Brauweiler A, Cambier JC. Effects of Src homology domain 2 (SH2)-containing inositol phosphatase (SHIP), SH2-containing phosphotyrosine phosphatase (SHP)1, and SHP-2 SH2 decoy proteins on Fc gamma RIIB1effector interactions and inhibitory functions. J Immunol. 2000;164:631-8

44. Griswold IJ, MacPartlin M, Bumm T, Goss VL, O'Hare T, Lee $\mathrm{KA}$, et al. Kinase domain mutants of Bcr-Abl exhibit altered 
transformation potency, kinase activity, and substrate utilization, irrespective of sensitivity to imatinib. Mol Cell Biol. 2006;26:6082-93.

45. Feldhahn N, Klein F, Mooster JL, Hadweh P, Sprangers M, Wartenberg M, et al. Mimicry of a constitutively active pre-B cell receptor in acute lymphoblastic leukemia cells. J Exp Med. 2005;201:1837-52.

46. Martin-Rodriguez P, Guerra B, Hueso-Falcon I, Aranda-Tavio H, Diaz-Chico J, Quintana J, et al. A novel naphthoquinone-coumarin hybrid that inhibits BCR-ABL1STAT5 oncogenic pathway and reduces survival in imatinibresistant chronic myelogenous leukemia cells. Front Pharm. 2018;9:1546.

47. Sharma SV, Gajowniczek P, Way IP, Lee DY, Jiang J, Yuza Y, et al. A common signaling cascade may underlie "addiction" to the Src, BCR-ABL, and EGF receptor oncogenes. Cancer Cell. 2006;10:425-35.

48. Yu L, Mohamed AJ, Simonson OE, Vargas L, Blomberg KE, Bjorkstrand B, et al. Proteasome-dependent autoregulation of Bruton tyrosine kinase (Btk) promoter via NF-kappaB. Blood. 2008;111:4617-26.

49. Jhou JP, Chen SJ, Huang HY, Lin WW, Huang DY, Tzeng SJ. Upregulation of FcgammaRIIB by resveratrol via NF-kappaB activation reduces B-cell numbers and ameliorates lupus. Exp Mol Med. 2017;49:e381.

50. Gallipoli P, Pellicano F, Morrison H, Laidlaw K, Allan EK, Bhatia $\mathrm{R}$, et al. Autocrine TNF-alpha production supports CML stem and progenitor cell survival and enhances their proliferation. Blood. 2013;122:3335-9.
51. Thieu VT, Nguyen ET, McCarthy BP, Bruns HA, Kapur R, Chang $\mathrm{CH}$, et al. IL-4-stimulated NF-kappaB activity is required for Stat6 DNA binding. J Leukoc Biol. 2007;82:370-9.

52. Cao S, Theodore S, Standaert DG. Fcgamma receptors are required for NF-kappaB signaling, microglial activation and dopaminergic neurodegeneration in an AAV-synuclein mouse model of Parkinson's disease. Mol Neurodegener. 2010;5:42.

53. Rushworth SA, Murray MY, Zaitseva L, Bowles KM, MacEwan DJ. Identification of Bruton's tyrosine kinase as a therapeutic target in acute myeloid leukemia. Blood. 2014;123:1229-38.

54. Yang Y, Shi J, Gu Z, Salama ME, Das S, Wendlandt E, et al. Bruton tyrosine kinase is a therapeutic target in stem-like cells from multiple myeloma. Cancer Res. 2015;75:594-604.

55. Kim E, Hurtz C, Koehrer S, Wang Z, Balasubramanian S, Chang $\mathrm{BY}$, et al. Ibrutinib inhibits pre-BCR(+) B-cell acute lymphoblastic leukemia progression by targeting BTK and BLK. Blood. 2017;129:1155-65.

56. Burger JA, Tedeschi A, Barr PM, Robak T, Owen C, Ghia P, et al. Ibrutinib as initial therapy for patients with chronic lymphocytic leukemia. N Engl J Med. 2015;373:2425-37.

57. Byrd JC, Brown JR, O'Brien S, Barrientos JC, Kay NE, Reddy $\mathrm{NM}$, et al. Ibrutinib versus ofatumumab in previously treated chronic lymphoid leukemia. N. Engl J Med. 2014;371:213-23.

58. Chanan-Khan A, Cramer P, Demirkan F, Fraser G, Silva RS, Grosicki $\mathrm{S}$, et al. Ibrutinib combined with bendamustine and rituximab compared with placebo, bendamustine, and rituximab for previously treated chronic lymphocytic leukaemia or small lymphocytic lymphoma (HELIOS): a randomised, double-blind, phase 3 study. Lancet Oncol. 2016;17:200-11. 